\title{
THE EFFECT OF VARIATION OF ELECTRIC CURRENT ON MICRO STRUCTURE AND VIOLENCE IN SS400 STEEL WELDING PROCESS USING THE SMAW METHOD
}

\author{
Irfan Adi Wibowo ${ }^{1}$, Suharno ${ }^{1}$, Yuyun Estriyanto ${ }^{1}$ \\ ${ }^{1}$ Mechanical Engineering Education, Universitas Sebelas Maret Surakarta \\ Email: irfanadiwibowo17@gmail.com
}

\begin{tabular}{|c|c|}
\hline KEYWORDS & ABSTRACT \\
\hline $\begin{array}{l}\text { Shielded Metal Arc Welding (SMAW) } \\
\text { Microstructure } \\
\text { Hardness }\end{array}$ & $\begin{array}{l}\text { The objective of the research was to find out the effect of current on } \\
\text { microstructure and hardness value in Alloy Steel SS400 before (raw material) } \\
\text { and after welding using Shielded Metal Arc Welding (SMAW). This research uses } \\
\text { experimental methods. The technique of analyzing data used was descriptive } \\
\text { and comparative research. The instruments used for testing microstructure and } \\
\text { hardness were Olympus Metallurgical Microscope and Vickers Hardness Tester. } \\
\text { Base on the result, it could be concluded that microstructure testing showed the } \\
\text { improved ferrite structure after welding. In raw material, ferrite structure } \\
\text { seemed to looks evenly, but the result of welding using SMAW welding method } \\
\text { with the current of I } 20 \text { A, } 130 \text { A, and } 140 \text { A showed that ferrite structure reduced } \\
\text { in each specimen so that perlite structure was very dominant. The hardness } \\
\text { value of the hardness result showed a different hardness level. The specimen } \\
\text { with the current of } 140 \text { A had a higher hardness level of } 231,055 \text { VHN than the } \\
\text { specimen with a current of } 120 \text { A ( } 219.222 \text { VHN) and } 130 \text { A ( } 223,333 \text { VHN). The } \\
\text { result of hardness testing on raw material was } 182,333 \text { VHN. This research } \\
\text { showed that welding using different current changed microstructure and } \\
\text { affected the hardness value of Alloy Steel SS400. }\end{array}$ \\
\hline
\end{tabular}

\section{INTRODUCTION}

Metal connections with welding methods are increasingly being used, in both building and machine construction. According to Cary (1998), the extent of the use of welding connection processes is caused by low costs, the implementation of relatively faster, lighter, and more varied forms of construction. However, it must be admitted that welded joints also have disadvantages, among others: the emergence of large voltage surges due to changes in microstructure in the area around the weld which causes a decrease in the strength of the material, and the presence of cracks due to the welding process (Jamasri, 1999).

According to (Wiryosumarto, 2000) not all metals have good weldability. Materials that have good weldability include low carbon steel. This steel can be welded by arc welding wrapped electrodes. Low carbon steel is commonly used for thin plates and general construction. In welding there will be freezing of the welding rate, which is not simultaneous; consequently, residual stress arises especially in the HAZ (Heat Affected Zone) and weld areas.

An alloy of low carbon steel is widely used for general construction because it has weldability and sensitivity to weld cracks. Low crack sensitivity is suitable for the welding process and can be used for thin welding plates or thick plates. The quality of the weld area is better than the parent metal. SS400 steel is generally described as low carbon steel, also called soft steel, widely used for the manufacture of steel bars, tanks, shipping, bridges, towers, lift aircraft and in machinery. In the construction design, many involve welding elements with welded joints as an alternative to connecting certain parts. 
Technically making welded joints requires high skill for the welders to obtain good quality connections. One of the deformed welded joints will eventually cause damage to the other joints, and finally, the construction can collapse which causes material losses that are not small and even fatal. Good welding quality, of course, requires an appropriate welding method. One of them is the welding method of SMAW (Shielded Metal Arc Welding) (Subardi, 2009).

In welding, SMAW electrodes have an essential role as a connecting material between two metals to be welded, and these electrodes consist of many sizes, types and are sold in a variety of brands. The electrodes used must be adjusted to the material to be welded, and the selection of the appropriate welding parameter parameters will improve the quality of the welding results. This welding uses E7018 electrode with a diameter of $3.2 \mathrm{~mm}$, then the currently used ranges from 115-165 Ampere. With these current intervals, the welding produced will be different (Soetardjo, 1997).

Adjusting the welding current will affect the weld. Low current will cause difficulty in igniting an electric arc. The electric arc that occurs becomes unstable. The heat that arises is not enough to melt the electrodes and the base material, so the result is a small and uneven weld, rigid, and less penetration. Conversely, if the current is too high, the electrode will melt too quickly and will result in a wider weld surface, and deep penetration was resulting in low tensile strength and increasing fragility from the welding results (Arifin, 1997).

To determine the effect of sharp variations in the current on the hardness and microstructure of SS400 alloy steel. Plate-shaped specimens were designed with a seam of welding V (Shielded Metal Arc Welding) (SMAW). In this study, the variations used were current strengths of $120 \mathrm{a}, 130 \mathrm{~A}$ and $140 \mathrm{~A}$.

\section{RESEARCH METHODS}

This research method uses the experimental approach. An experimental research carried out in the laboratory with the conditions and equipment completed to obtain data to study the physical and mechanical characteristics of the results of welding. The material used is SS400 Steel Alloy. The material will be welded with a current variation of 120A, 130A, 140A using the welding method Shielded Metal Arc Welding (SMAW).

The process of welding specimens was carried out at the Las INLASTEK Laboratory, and for microstructure testing and hardness of test, specimens were carried out at the Technical Materials Laboratory Program, Department of Mechanical and Industrial Engineering, Faculty of Engineering, Gadjah Mada University, Yogyakarta. Tests carried out include metallographic tests (microstructure) and hardness tests. The test equipment used in this study was the Olympus Metallurgical Microscope machine, the Vickers Micro Hardness Tester machine. In the hardness of welding results with a specific current strength, the area tested is the weld area, the HAZ region, the base material area.

The specimens used in this study amounted to 4 pieces, three welding specimens and one material without welding. The size of each sample is $80 \mathrm{~mm} \times 30 \mathrm{~mm} \times 12 \mathrm{~mm}$. The welded connection uses seam $\mathrm{V}$, and the type of welding uses SMAW welding (Shielded Metal Arc Welding).
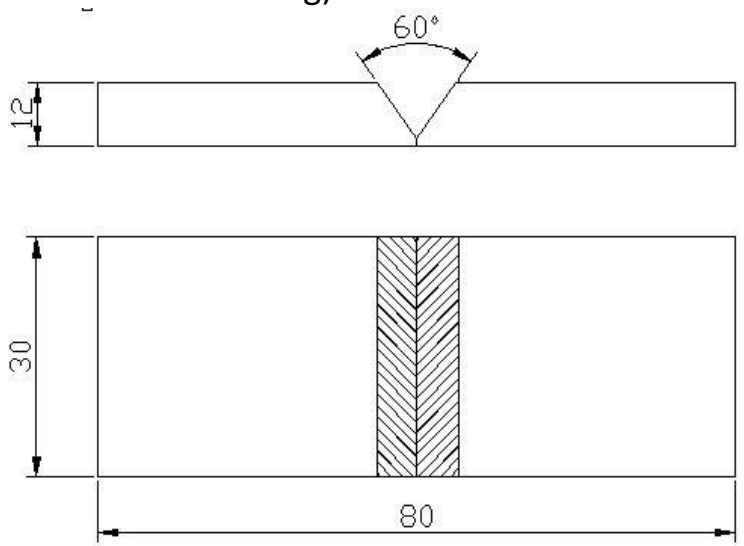

Figure 1. Dimensions of Weld Specimens

The data analysis technique used in this study is an analysis with a comparative descriptive method. The data obtained in this study were in the form of hardness data, and microstructure as well as from observations then analyzed descriptively.

\section{RESULTS AND DISCUSSION}

In this study microstructure, testing aims to determine the microstructure of the SMAW welding test specimens. 


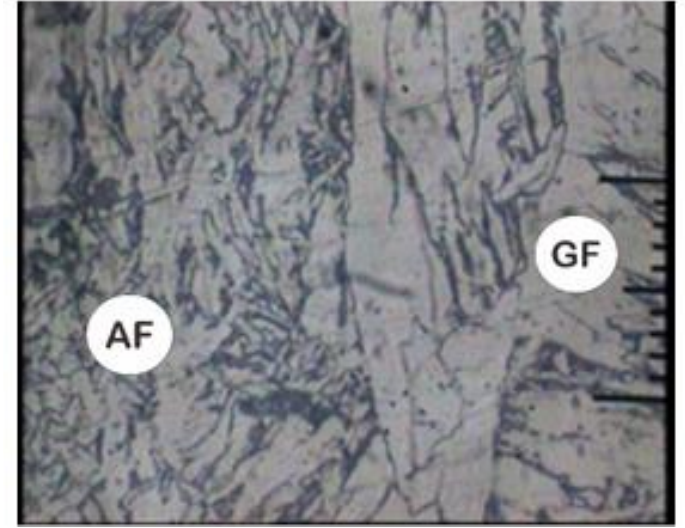

(a)

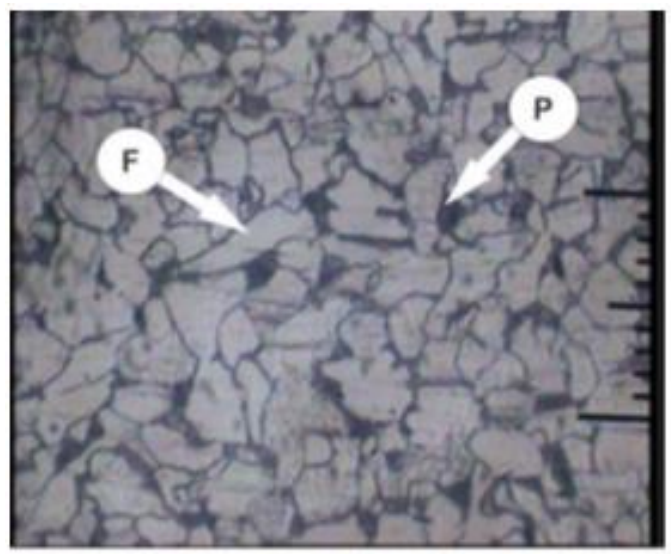

(c)

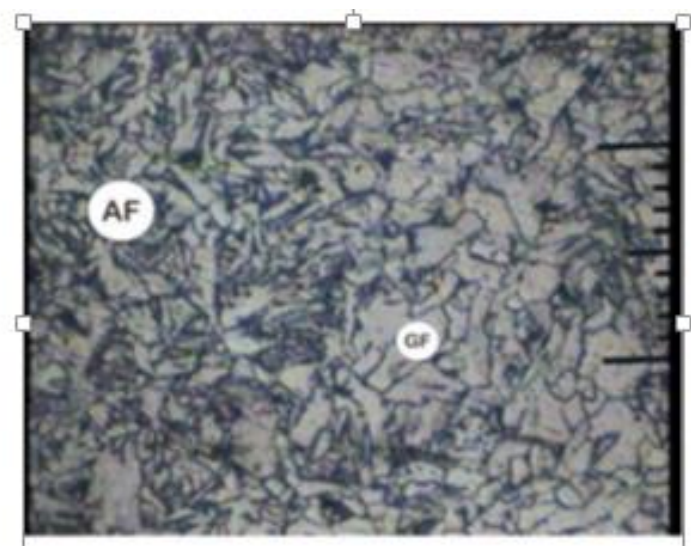

(b)

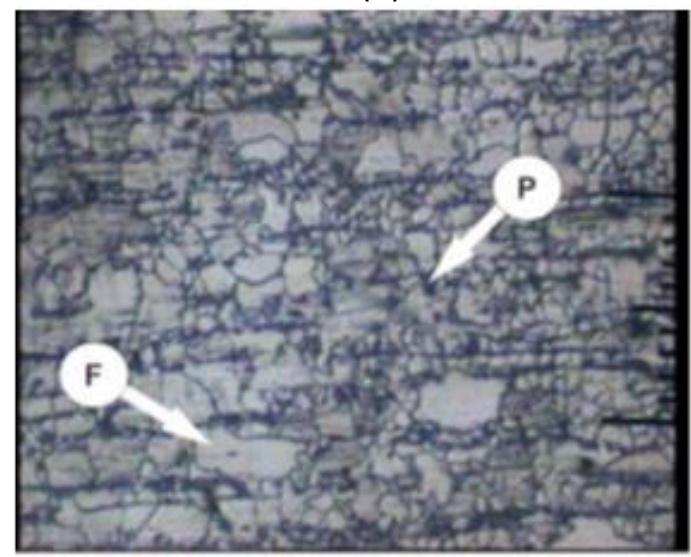

(d)

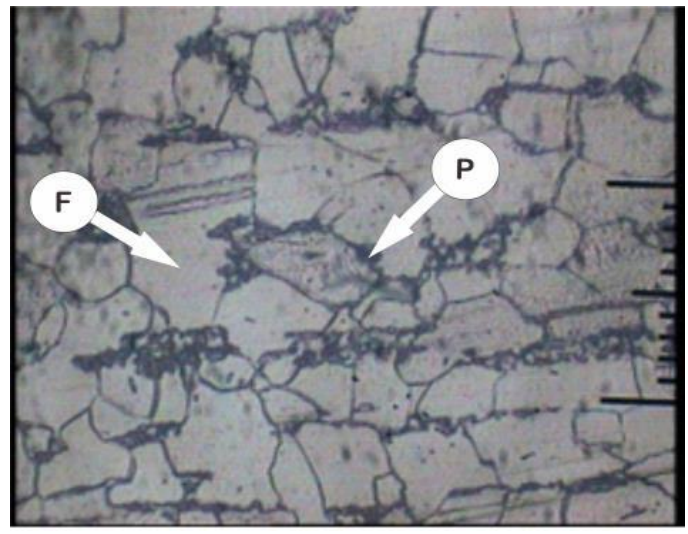

(e)

Figure 2. Microstructure of Current 120 A (a) Welding Area (b) HAZ Welding (c) HAZ (d) Main HAZ (e) Main Steel

From figure 2, above shows the results of microstructure test on weld metal, weld metal boundary with HAZ, HAZ region, HAZ boundary with parent metal and parent metal with $120 \mathrm{~A}$. current strength in weld metal shows acicular (AF) and grain boundary ferrite (GF). In the figure, the photos of microstructure for grain boundary ferrite are large, and the structure for acicular ferrite is soft-grained and dominates the area.

The weld metal boundary area with HAZ shows acicular ferrite (AF) and grain boundary ferrite (GF) microstructure. In the figure, the microstructure image for acicular ferrite looks small and the structure for grain boundary ferrite looks large.

In the HAZ region, the HAZ boundary is weld metal, and the parent metal shows ferrite and pearlite microstructures. In the picture, the microstructure photo for pearlite is entirely dominating the area, and the structure for ferrite looks small. 


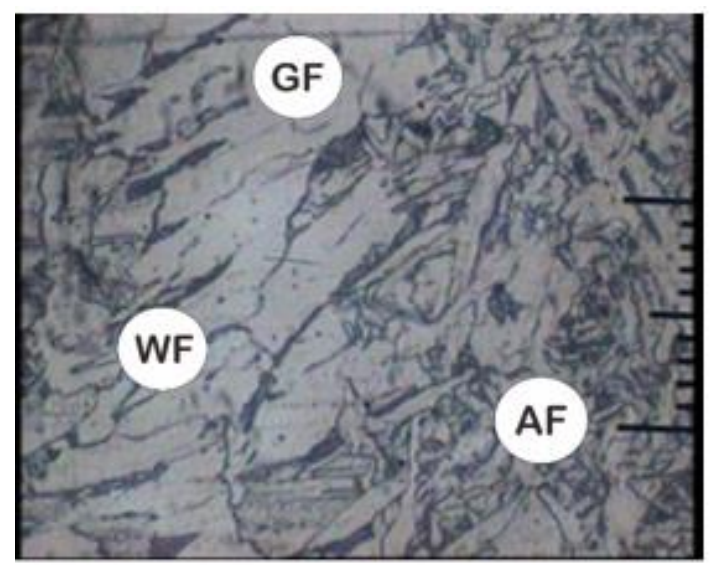

(a)

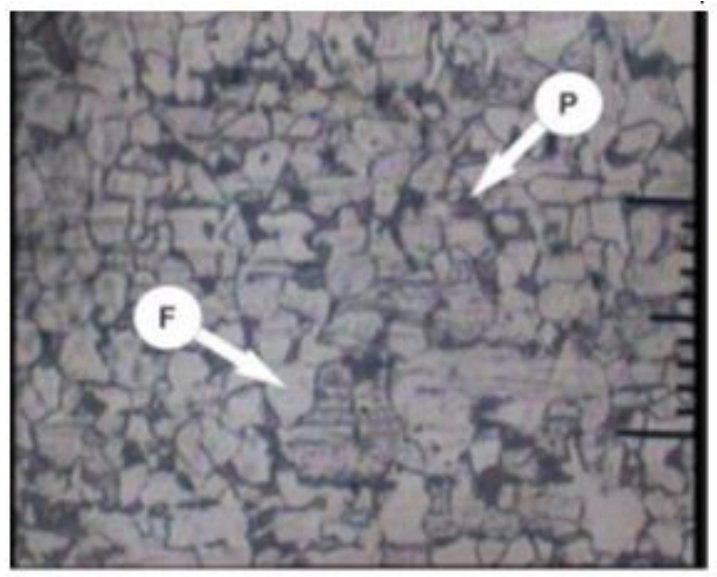

(c)

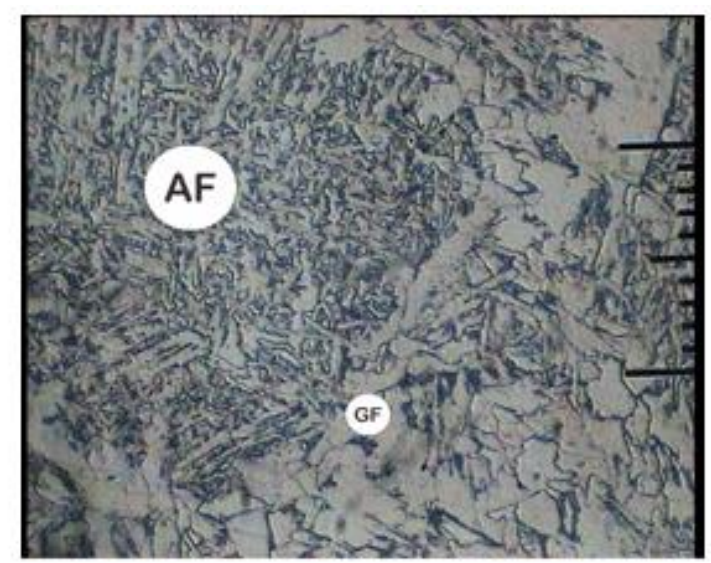

(b)

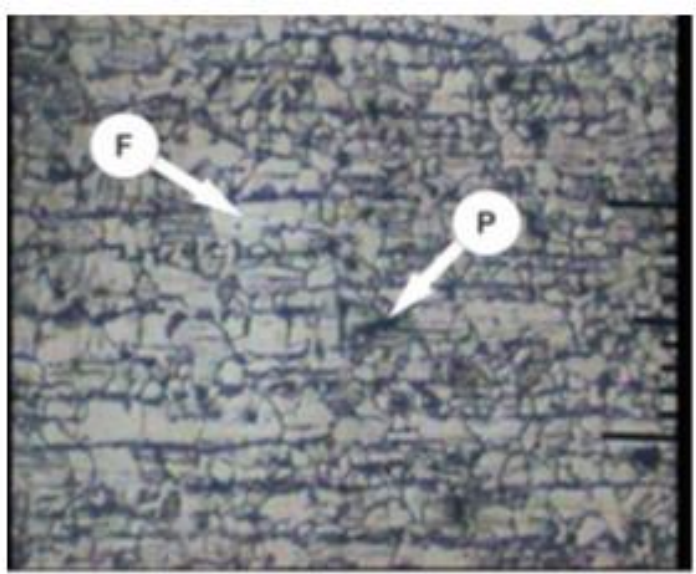

(d)

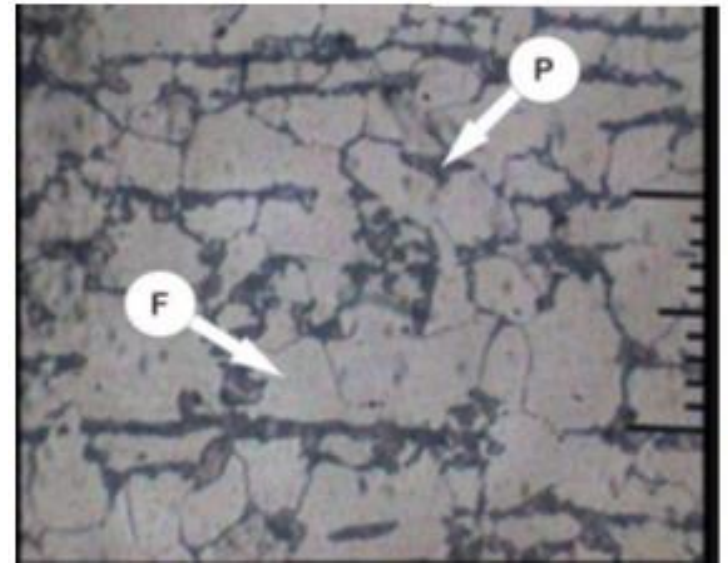

(e)

Figure 3. The Microstructure of Current 130 A (a) Welding Area (b) HAZ Welding (c) HAZ (d) Main HAZ (e) Main Steel

In Figure 3 above shows the results of microstructure test on weld metal, weld metal boundary with HAZ, HAZ region, HAZ boundary with parent metal and parent metal with $130 \mathrm{~A}$. current strength in weld metal shows acicular ferrite (AF) microstructure, boundary ferrite Grain and Widmanstatten (WF) grain boundary ferrite (GF). In the figure, the microstructure for grain boundary ferrite looks smaller when compared to $120 \mathrm{~A}$ currents and the structure for acicular ferrite (AF) still dominates the area. Widmanstatten's ferrite amount (WF) in the image is quite large and is found along the grain boundary line. It resulted in an increase in hardness in the weld metal area when compared to $120 \mathrm{~A}$. current specimens.

The weld metal boundary area with HAZ shows acicular ferrite (AF) and grain boundary ferrite (GF) microstructure. In the figure, the microstructure for acicular ferrite (AF) looks smoother than 120 A Flow and the structure for grain boundary ferrite (GF) still dominates the area.

In the HAZ region, the HAZ boundary with the parent metal and the parent metal shows ferrite and pearlite microstructures. In the picture, the microstructure for ferrite is less than at 120; A and the structure for pearlite 
appears to dominate the area. This results in the HAZ region, the HAZ boundary with the parent metal, and the parent metal harder than the $120 \mathrm{~A}$. current specimen.

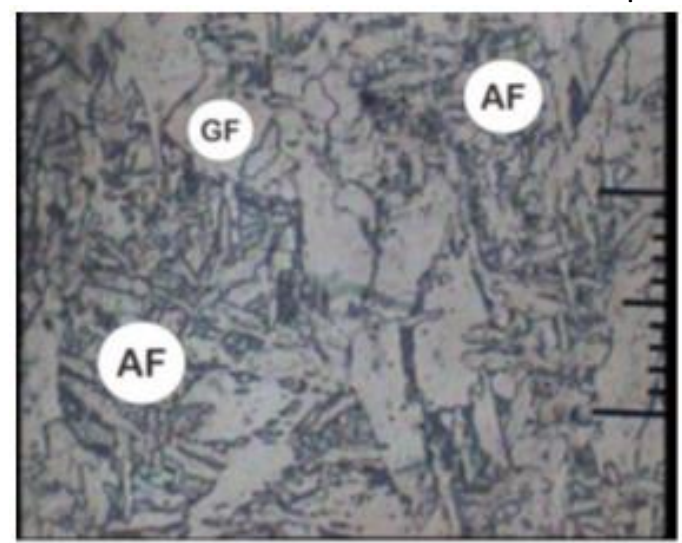

(a)

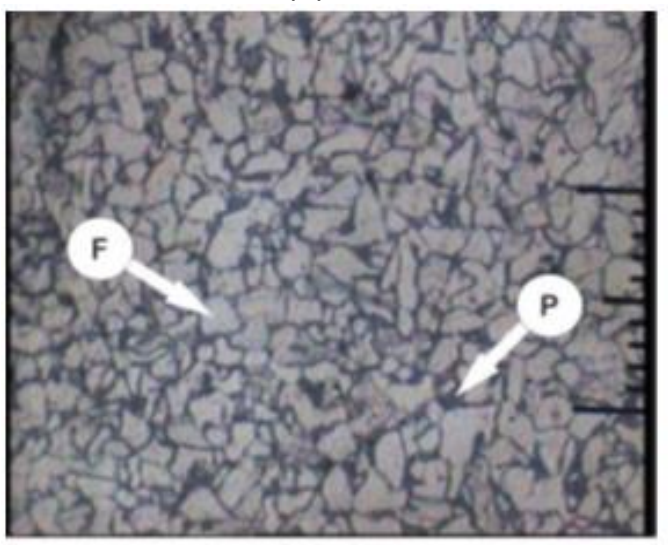

(c)

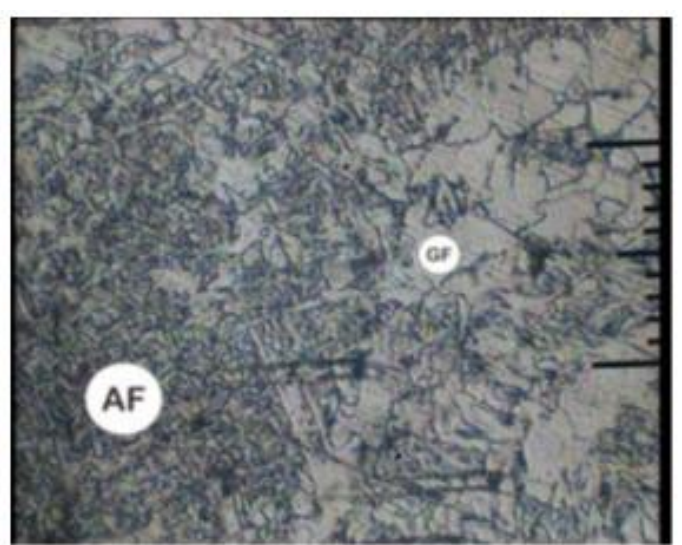

(b)

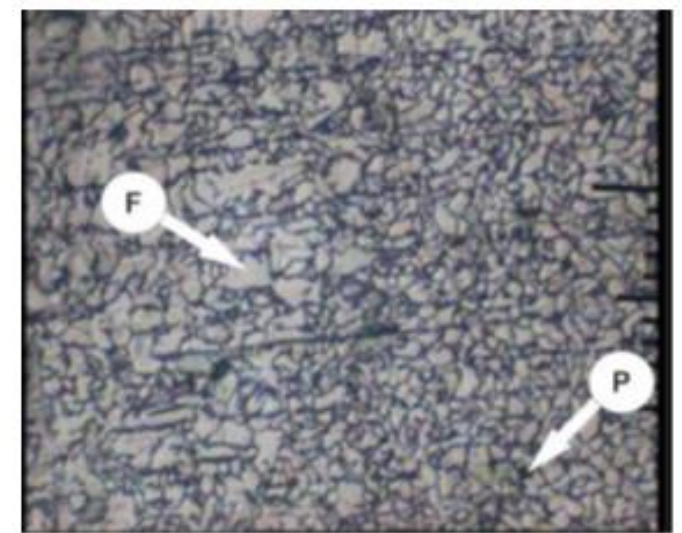

(d)

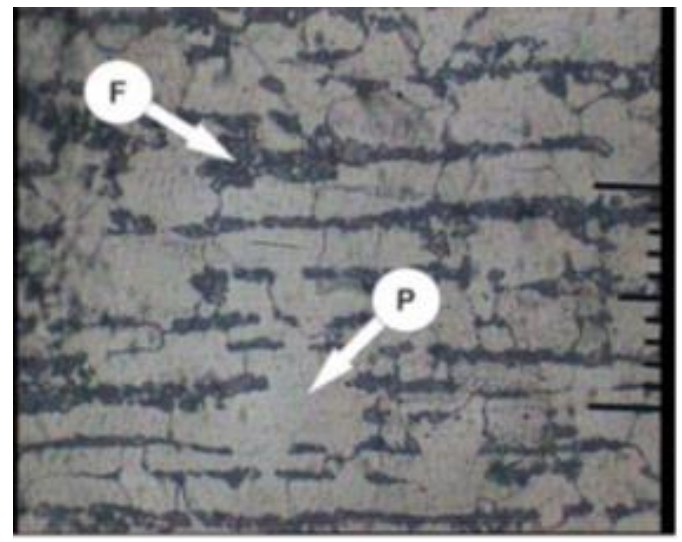

(e)

Figure 4. Microstructure Current 140 A (a) Welding Area (b) HAZ Welding (c) HAZ (d) Main HAZ (e) Main Steel

In Figure 4 above shows the results of microstructure test on weld metal, weld metal boundary with HAZ, HAZ region, HAZ boundary with parent metal and parent metal with a current strength of $140 \mathrm{~A}$. In weld, metal shows the structure of acicular ferrite (AF) and boundary ferrite grain boundary ferrite (GF). In the figure, the microstructure image for grain boundary ferrite is small, and the structure for soft-grained acicular ferrite dominates the area when compared to $120 \mathrm{~A}$ and $130 \mathrm{~A}$. It is consistent with the research (Rananggono, 2010) "If the current is used high, then the grain the formed becomes smooth, on the contrary, if the current used is small then the grain becomes large ".

The weld metal boundary area with HAZ shows the acicular and grain boundary ferrite (GF) microstructure. In this picture, the microstructure image for grain boundary ferrite is small, and the structure for soft-grained acicular ferrite dominates the area when compared to 120 Ampere and 130 Ampere currents.

In the HAZ region, the HAZ boundary with the parent metal and the parent metal shows ferrite and pearlite microstructures. In the figure, the structure photos for ferrite appear smaller, and the pearlite microstructure dominates the area more than at $120 \mathrm{~A}$ and $130 \mathrm{~A}$ Currents 


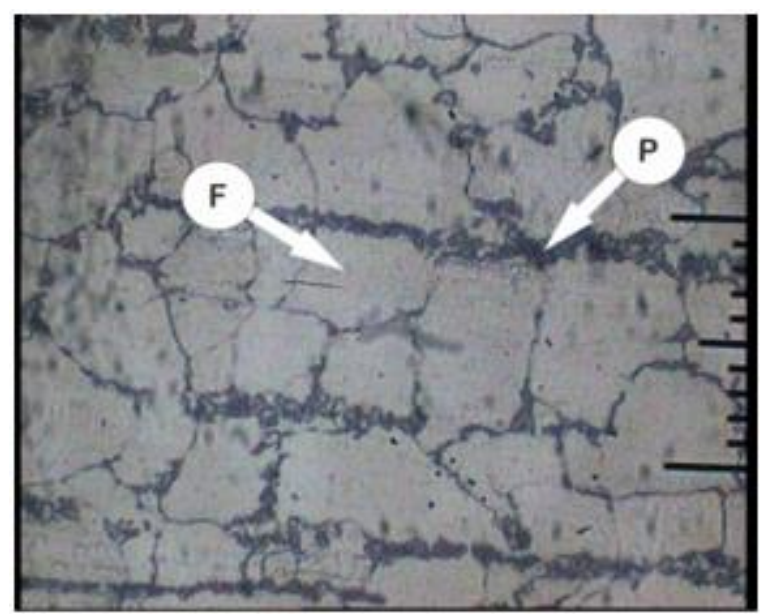

Figure 5. Micro Structure of Raw Material

Figure 5 shows the results of the microstructure of raw material test (without welding). Visible ferrite structure is slightly more even when compared to the base material; consequently, material without welding tends to be somewhat softer than the base material.

The highest hardness value is found in the weld metal area with a current of $140 \mathrm{~A}$ which is $272 \mathrm{VHN}$. Whereas in the weld area with 130 A current strength of $256 \mathrm{VHN}$ and $120 \mathrm{~A}$ current force of 248,333 VHN. This is following the research (Santoso, 2006) "If the electric current given is greater, then the heat input (Heat Input) given to the specimen will be even greater. In small electric currents, the hardness value of the specimen will tend to be lower and inversely proportional if the electric current used in welding is getting bigger ".

The weld area in the three specimens tended to be harder when compared to HAZ and the parent metal. Based on the observation of the microstructure, the weld area in the current $140 \mathrm{~A}$ tends to have more acicular ferrite compared to the weld area at $120 \mathrm{~A}$ and $130 \mathrm{~A}$. The structure is the most effective structure in holding the load so that the area becomes harder. The smaller value of violence from the center of the weld is also under the Easterling statement (1983) which states that the value of force tends to decrease from the melting limit to the base metal depending on grain size (microstructure). It is because the farther away from the center of the weld, the effect of heat will decrease.

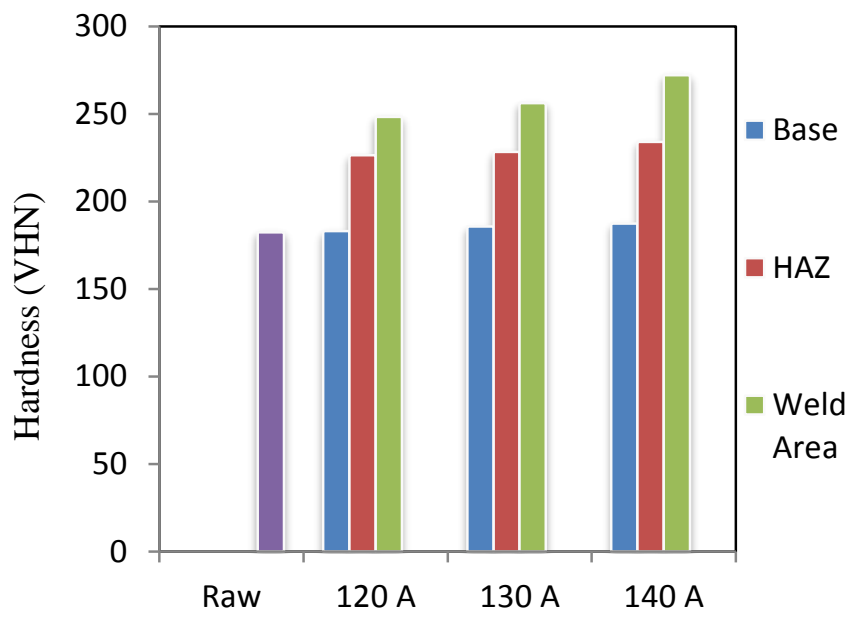

Figure 6. Graph of the Vickers Hardness Test Average Value

Hardness test results of specimens without welding (raw material) is 182,333 VHN. When compared with the three welding specimens using different current strengths, the level of hardness in raw material tends to be lower. This result is following the research (Ahmad Soleh, 2016) which states that the higher the welding current, the higher the value of the hardness. Increasing the value of hardness in welding specimens is due to changes in microstructure, namely increasing the structure of pearlite. 


\section{CONCLUSION}

There is a strong influence on the microstructure of the welding results of SS400 alloy steel with a strong current of $120 \mathrm{~A}, 130 \mathrm{~A}$, and $140 \mathrm{~A}$. In the HAZ area, slow cooling occurs so that the grain in the microstructure will be enlarged, while in the acicular ferrite welding area is the most dominant weld results with a current of $140 \mathrm{~A}$. There is a strong influence on the level of hardness of the welding results of SS400 steel alloy with a current strength of $120 \mathrm{~A}, 130 \mathrm{~A}$ and $140 \mathrm{~A}$. Specimens with a current strength of $140 \mathrm{~A}$ have a higher average hardness level of 231,055 $\mathrm{VHN}$ when compared to a strong current specimen $120 \mathrm{~A}$ of $219,222 \mathrm{VHN}$ and $130 \mathrm{~A}$ of 223,333 VHN. The hardness test results without specimens (raw material) amounted to $182,333 \mathrm{VHN}$.

\section{REFERENCES}

Ahmad Soleh, Anjis. (2016). Analisa Pengaruh Kuat Arus terhadap Struktur Mikro, Kekerasan, Kekuatan Tarik pada Baja Karbon Rendah dengan Las Smaw Menggunakan Jenis Elektroda E7016. Skripsi Dipublikasikan. Universitas Wahid Hasyim, Semarang.

Arifin, S. (1997). Las Listrik dan Otogen. Jakarta : Ghalia Indonesia.

Cary, H.B. (1998). Modern Welding Technology. New Jersey, USA: Prentice Hall.

Easterling, Kenneth. (1983). Introduction to the Physical Metallurgy of Welding. London : Butterworths and Co Ltd. Jamasri \& Subarmono. (1999). Pengaruh Pemanasan Lokal terhadap Ketangguhan dan Laju Perambatan Retak Plat Baja. Yogyakarta : Media Teknik UGM

Rananggono, D. (2010). Studi Kekuatan Mekanik dan Struktur Mikro Hasil Pengelasan SMAW dengan Variasi Preheat dan Postheat Menggunakan Metode Pendinginan Cepat dan Pendinginan Lambat. Jurnal IImiah Teknik Kelautan Umsida. Diperoleh pada 17 maret 2017, dari digilib.its.ac.id/ITS-Undergraduate.

Santoso, Joko. (2006). Pengaruh Arus Pengelasan terhadap Kekuatan Tarik dan Ketangguhan Las SMAW dengan Elektroda E7018. Skripsi Tidak Dipublikasikan. Universitas Negeri Semarang, Semarang.

Soetardjo. (1997). Teknologi Pengelasan Logam. Jakarta : Rineka Cipta.

Subardi. (2009). Pengaruh dari suhu area pemanasan terhadap kekerasan dan mikrostruktur pada pengelasan baja ST 37. Yogyakarta : STTNAS

Wiryosumarto, H. (2000). Teknologi Pengelasan Logam. Jakarta: Erlangga. 